\title{
Beckett and Coetzee: The aesthetics of insularity ${ }^{1}$
}

Nicholas Meihuizen

Department of English

University of Zululand

KWA-DLANGEZWA

\section{Abstract}

\section{Beckett and Coetzee: The aesthetics of insularity}

The permutations of sentence elements in Beckett's Watt have the impersonality (almost) of mathematics. The variations of combinations of the same elements in certain sections of the book could have been performed by a computer. It is noteworthy that J.M. Coetzee indeed subjects Beckett's work to computer analysis, as if he responds to aspects of it by mirroring in his approach to it the essence of its automatism/autism/insularity. Coetzee's own insularity, though, takes its bearing primarily from the socio-political state; Beckett's, if linked to this, primarily from the individual estranged by the contemporary world. But Beckett shares with Coetzee the informing thrift necessary for the establishment of an aesthetics of insularity.

\section{Introduction}

In an autobiographical sketch at the conclusion of Doubling the point: Essays and interviews (1992), Coetzee (from what he terms the vantage point of the "island" created by the dialogue with David Attwell, his interviewer, and from which he views himself symptomatically in the insulated third person) ${ }^{2}$ tells of his early work on Beckett: "He writes a formalistic analysis of Beckett, concentrating on texts from a period in Beckett's life when Beckett too was

1 This article is a revised version of a paper originally delivered at the International Association for the Study of Anglo-Irish Literature (IASAIL) conference, "Insulae, Islands, Ireland", hosted by the University of Sassari, Sardinia, 7-10 September 1994.

2 But let it be noted that Coetzee's use of the third person accurately conveys his present sense of being distanced from an earlier self. 
obsessed with form, with language as self-enclosed game" (Coetzee, 1992:393). The context would have it that his work on Beckett is an extension of his own "alienness". He feels "alien" at the University of Texas, Austin, where he conducts his "formalistic analysis of Beckett" - perhaps not a surprising fact concerning a young man in a foreign country - but he then traces (in his terms) "this feeling (of alienness, not alienation) further back in time". He tells of his early years in South Africa, where the sense of alienness is reinforced by the socio-political situation of an Afrikaner attending English-speaking schools. He tells of the stigmatisation this entails from his own people, who, in an adroitly engineered stratagem that culminates in the Nationalist party victory of 1948, are intent on maintaining the purity of the Afrikaner race. In Anatomy of apartheid, H. Lindsay Smith (1979:2) records the Afrikaner's fierce desire "for his tribe to remain paramount and for his shelter to be found in tribal affinities. Thus ... he has come to feel that his duties lie not solely to the God that he worships, nor to the country in which he lives but to the sublimation of self to the tribe" (Smith, 1979:2). A type of tribal separatism informs Coetzee's alienness, a type of separatism (to anticipate a later thread in my discussion) also apparent in Grand Apartheid, where the effectiveness of state control is dependent upon the sublimation of self to the tribe. Intellectual "miscegenation", as practised - however unwittingly - by the young Coetzee, undermines the very basis of separatist ideology, and, like sex across the colour bar, must be dealt with in severe terms. The biographical evidence, then, suggests a strong link between Coetzee's individual situation and the sociopolitical situation in his country. But Coetzee is never overt in his fictional dealings with South African history. In fact, these dealings might, in their obliqueness, incorporate the following: "the Wittgensteinian account of the relationship between fiction and historical discourse", as in Ricoeur's "narrative discourse" (which effectively links literature and history); "recent theories of metafiction", as in Patricia Waugh's and Linda Hutcheon's location of reflexivity within politics, "the semiotics of the later Prague School", as encoded in Mukarovsky's insistence that literature has access to the "total context of social phenomena"; as well as deconstruction, Marxism and Lacanian psychoanalysis (Attwell, 1990:96-106). Whatever the degree of obliqueness involved in Coetzee, the above instances suggest we need to take history seriously in a consideration of his work. My own point of departure is the connection between individual and history as encoded in Coetzee's word alienness. Amongst other matters to do with art and insularity, I want to distinguish, in what follows, between this sense of alienness (of the lone individual being socially outside a dominant culture), and the alienation (a more general sense of pervasive psychological estrangement) underlying Beckett's work. 


\section{Coetzee and alienness}

Coetzee's literary-historical perception of his country is permeated by notions connected with insularity:

... the topos of the garden, the enclosed world entire to itself, is more extensive than the Judaeo-Christian myth of Eden. In its isolation from the great world, walled in by oceans and an unexplored northern wilderness, the colony of the Cape of Good Hope was indeed a kind of garden (Coetzee, 1988:3).

Within the cultural ambience originally generated by this garden are two topographically bound types of insularity:

One dream topography that the South African pastoral projects is ... of a network of boundaries crisscrossing the surface of the land, marking off thousands of farms, each a separate kingdom ruled over by a benign patriarch with, beneath him, a pyramid of contented and industrious children, grandchildren, and serfs. But there is a rival dream topography as well: of South Africa as a vast, empty, silent space, older than man, older than the dinosaurs whose bones lie bedded in its rocks, and destined to be vast, empty, and unchanged long after man has passed from its face. Under such a conception of Africa ... the task of the human imagination is to conceive not a social order capable of domesticating the landscape, but any kind of relation at all that consciousness can have with it (Coetzee, 1988:6-7).

The "alienness" here is of a transcendent, mythic dimension, the insularity of a defining Other which helps constitute tribal separatism, which, combined with the insularity of the first order - farm, fort, island which appear in his work gives impetus to the mythic topologies so characteristic of Coetzee's own version of the pastoral.

\section{The poetics of failure}

Considering the above emphases on insularity and separateness in Coetzee's perception of his historico-cultural inheritance, it is significant that one of his essays on Beckett should contain in a prominent position this quotation from "Imagination Dead Imagine". "Islands, waters, azure, verdure, one glimpse and vanished, endlessly, omit" (in Coetzee, 1992:43). Coetzee comments:

The first four words, flagrantly composed though they may be, leading associatively one to the next via even the bathos of myme, threaten to assert themselves as illusion, as The Word in all its magical autonomy. They are erased ('omit') and left like dead leaves against a wall. The sentence thus embodies neatly two opposing impulses that permit a fiction of net zero: the 
impulse toward conjuration, the impulse toward silence. A compulsive selfcancellation is the weight imposed on the flight of the sentence toward illusion; the fiction itself is the penance imposed on the pursuit of silence, rest, and death. Around the helix of ever-decreasing radius described by these conditions Beckett's art moves toward its apotheosis, the one-word text 'nothing' under the title 'Fiction'.

But if "islands" is the "illusion" it is also the "death", carrying in itself as an image the conditions of silence, rest and, by extension, death. Beckett and Coetzee in their lives and fiction are island-dwellers, deeply familiar with the impulses of silence and death, which are, at times, the prime objects of their conjuration; certainly both value immensely the informing thrift behind, for instance, the spare but richly packed death scene at the conclusion of Coetzee's Age of iron (1990:181), or the understated sense of loss and relinquishment in the conjunction between the pain-racked Mr. Kelly and his free-flying kite at the end of Murphy (1973:158). In emphasising Coetzee and Beckett's fascination with a product of net zero, however, we must not lose sight of Coetzee's affirmative capability. Coetzee's following words (concerning works by Nabokov, Barth and Beckett) help to isolate a linguistically bound, existential scepticism not really applicable to his own project:

The poetics of these works is a veritable poetics of failure, a program for constructing artifacts out of an endlessly regressive, etiolated selfconsciousness lost in the labyrinth of language and endlessly failing to erect itself into autonomy. The poetics of failure is ambivalent through and through, and part of its ambivalence is that it must parade its ambivalence; thus Beckett can speak of an art that is 'the expression that there is nothing to express' (Coetzee, 1992:87). ${ }^{3}$

\section{The dialectic between form and history}

I think Coetzee longs at times for the anonymity of zero, hence another reason for his attraction to Beckett, but something like a social responsibility forces an

3 In a dialogue with Georges Duthuit, Beckett observes: "I speak of an art turning from [the plane of the feasible] in disgust, weary of its puny exploits, weary of pretending to be able, of being able, of doing a little better the same old thing, of going a little further along a dreary road." To Duthuit's question, "And preferring what?", Beckett responds, "The expression that there is nothing to express, nothing with which to express, nothing from which to express, no power to express, no desire to express, together with the obligation to express" (Kenner, 1973:30). 
almost traditionalist sense of authorship on him. Despite his regard for formalism, he sees his work primarily in relation to history, rather than the labyrinth of language, to the point where he can conceive of only two options for the novel, to supplement history, or be its rival (Attwell, 1990:101). Never putting the notion of autonomy to question, he chooses the latter, thereby embracing a difficult relationship in which historical immanence and transcendence both play a part. In the context of postmodemism and the selfreflexive work, this diachronic conscience might extract from him the following observation:

Anti-illusionism - displaying the tricks you are using instead of hiding them - is a common ploy of postmodernism. But in the end there is only so much mileage to be got out of the ploy. Anti-illusionism is, I suspect, only a marking of time, a phase of recuperation, in the history of the novel (Coetzee, 1992:27).

If Beckett celebrates expressing the fact that there is nothing to express, Coetzee, though still fascinated by "language as self-enclosed game", is not, in the end, content with such semantic and existential diminishment. Like Patricia Waugh, he would use the terms of a type of postmodern diminishment to generate a new sense of agency. Thus Waugh's following observation is also pertinent in the case of Coetzee:

... even if [feminism] draws upon postmodern aesthetic forms of disruption, it cannot repudiate entirely the framework of Enlightened modernity without perhaps fatally undermining itself as an emancipatory politics. In proceeding through the demands of political practice, feminism must posit some belief in the notion of effective human agency (Waugh, 1992:195).

Regarding the link between his attraction for a formalistic approach and the work of Beckett, Coetzee (1992:23) himself admits: "Beckett's prose, which is highly rhetorical in its own way, lent itself to formal analysis". Coetzee then makes an observation that sheds further light on the distinction between alienness and alienation:

I should add that Beckett's later short fictions have never really held my attention. They are, quite literally, disembodied ... The late pieces speak in post-mortem voices. I am not there yet. I am still interested in how the voice moves the body, moves in the body.

In other words, I would hazard, Beckett's alienation turns inwards, to a point of maximum internalisation. At the same time, we should not lose track of a diametrically opposed type of alienation in Beckett, based on an inability to move beyond face value; consider Watt's version of the postmodern condition: 
The most meagre, the least plausible, would have satisfied Watt, who had not seen a symbol, nor executed an interpretation, since the age of fourteen, or fifteen, and who had lived, miserably it is true, among face values all his adult life ... (Beckett, 1970:70).

But both types of alienation result in the same psychological estrangement. Coetzee's alienness has a social dimension, relating to the invariable sociopolitical nature of the albeit mythical and elegantly epistemic (or formalised) frames he employs in his fiction. The dialectic between form and history in Coetzee is summarised by David Attwell as, "the difficult, seemingly intractable relationship in all Coetzee's novels between, on the one hand, system, structure, synchrony, acts of apprehension or consciousness, and on the other, events, diachrony, and history" (Attwell, 1990:95). This is not to deny a similar difficult relationship in Beckett, but Coetzee is justified, I think, in defining the voice in the later work of Beckett as "post-mortem" (a formulation that might suggest an oblique play with the disembodied aspect of the post-modern voice).

\section{Talking about delight}

Far from simply being attracted by the austerity of net zero, Coetzee gives "sensuous delight" as a principal reason for his studying Beckett:

Beckett's prose, up to and including The Unnameable, has given me a sensuous delight that hasn't dimmed over the years. The critical work I did on Beckett originated in that sensuous response, and was a grasping after ways in which to talk about it: to talk about delight (Coetzee, 1992:20).

That Coetzee's highly formalistic ways of approaching Beckett can be the source of "sensuous delight" must suggest something about Coetzee's nature, prone to the reassurances of a type of formalism, a formalism he characterises as "a capsule in which he can live, a capsule in which he need not breathe the air of the world" (Coetzee, 1992:393). This capsule is not unlike the "little world" of the padded cell, so admired by Murphy (Beckett, 1973:103), or the world of the supremely indifferent mental patients:

... the impression [Murphy] received was of that self-immersed indifference to the contingencies of the contingent world which he had chosen for himself as the only fehicity and achieved so seldom (Beckett, 1973:96).

In analysing Beckett's Lessness (a work which in its second half repeats the words contained in the first half, but in a different order), Coetzee arrives at the conclusion:

This endless enterprise of splitting and recombining is language, and it offers not the promise of the charm, the ever-awaited magical combination that will 
bring wealth or salvation, but the solace of the game, the killing of time (Coetzee, 1992:21).

Is "solace" for Coetzee synonymous with "sensuous delight"? Whatever our response to this question, the centripetal nature of Beckett's ludism is surely sympathetic to the type of self-encased reactions Coetzee has in mind. One of Beckett's games, of course, turns on linguistic permutation. For example, Murphy calculates the total permutability of the order in which six biscuits can be eaten: "edible in a hundred and twenty ways!" (Beckett, 1973:57). This is a foretaste, so to speak, of the permutations so intrinsic to the formalism of Watt.

The permiutations of sentence elements in Watt have the impersonality (almost) of mathematics. On page 27 of Watt we find the first permutations based on "voices, singing, crying, stating, murmuring": "Now these voices, sometimes they sang only, and sometimes they cried only, and sometimes they stated only, and sometimes they murmured only, and sometimes they sang and cried, and sometimes they sang and stated, and sometimes they sang and murmured", and so on and so (predictably and intolerably) on. We enter here into Watt's computer-like mind, as impersonal as the electrical unit of his name. The variations of combinations of the same elements in certain sections of the book could have been performed by a computer, except for the fact that Beckett's humour surfaces every now and again, such as in the conclusion to over a page of variations on the combinations of sock, stocking, boot, shoe or slipper Knott wore on his feet: "And sometimes he went barefoot" (1970:200-201). We never find a responsive humour in Coetzee. More characteristically, Coetzee, indeed, subjects Beckett's work to computer analysis, as if his sensuous response to it can only be determined by the essence of its automatism/autism/insularity. In this he seems to bring to completion Adorno and Horkheimer's conception of the Enlightenment thinking process: "Thinking objectifies itself to become an automatic, self-activating process; an impersonation of the machine that it produces itself so that ultimately the machine can replace it" (Adorno \& Horkheimer, 1986:25). But if Coetzee's response to Beckett is what Beckett wryly had in mind as the ideal conclusion to his project, Coetzee, again, emphasises the formalism of the game rather than such self-undermining modernist irony. In his essay on Lessness Coetzee "ran a program which mapped repetitions occurring at different levels - the phrase, the sentence, and the paragraph", and concluded with the previously quoted sentence:

This endless enterprise of splitting and recombining is language, and it offers not the promise of the charm, the ever-awaited magical combination that will bring wealth or salvation, but the solace of the game, the killing of time (Coetzee, 1992:21). 
In other words language offers an ideal of formalistic ludism, apparent in Coetzee's own fiction in, to use Attwell's terms, "the temporal reversals and structural parallelisms of Dusklands", "the numbered paragraphs and episodic repetitions of In the heart of the country", and "the crafted intertextuality of Foe" (Attwell, 1990:115). In Attwell's view, the distancing of authorial presence involved in such formalism "has the effect of alluding to a source of non-authorial, cultural and by implication, historical conditioning" (Attwell, 1990:116), as opposed to Coetzee's own synchronic interpretation of Beckett's formalism. For example, Attwell notes that Coetzee chooses to neglect the "circumstantial causes" behind "the deliberate and persistent evasion" of the "obsessive state of mind" as recorded in Watt (95). The book was written in the context of Beckett's trying to keep one step ahead of the Gestapo. Kenner (1973:22) indicates that Beckett left Paris "because of the Germans", and "from pillar to post"' in the unoccupied zone composed Watt.

\section{Insularity}

According to the Oxford English Dictionary, the word "insular" has four distinct meaning clusters, which sort with the formalism of Beckett's interminable permutations, Coetzee's programmatic responses to Beckett, and, indeed, Coetzee's own fiction:

\section{1. of, relating to, an island \\ 2. remote, detached, aloof \\ 3. illiberal, narrow-minded \\ 4. isolated, separated}

A machine-like predictability - commensurate with Beckett's formalism and Coetzee's response to it - sets the conditions for the type of autism inherent in senses 1, 2, and 4, but "remote, detached, aloof", primarily relate to Beckett's internally conditioned alienation, while "isolated, separated", relate to Coetzee's sense of externally conditioned alienness (which also, of course, has an internal correlative). The antagonism that might reinforce the isolation appears in cluster 3, "illiberal, narrow-minded". And with this "illiberality" in mind, a case can be made for linking insularism and apartheid. Apartheid, not at odds with that modernist imperative to individuate, feeds, as we have seen, into Coetzee's sense of the isolated self and a separatist society. Thus he is tempted by the topography of the island, as in, most obviously, Foe, but his characters in their impermeability are also islands. In Foe the insular Friday, subject to the imperialistic domination of Crusoe and Susan Barton, has a useless stump for a tongue, metonymic, if anachronistic, symbol of the voiceless majority of the apartheid state (Coetzee, 1986:22). This absence of a tongue is fundamentally linked with the linguistic contestation involved in tribal 
separatism and individuation (Smith, 1979:17). Again, then, Coetzee's insularity reflects fairly obviously (though not in a simple way) on the sociopolitical state, Beckett's insularity reflects primarily on "acts of apprehension or consciousness" (cf. Attwell, 1990:95). By rivalling history Coetzee demands an independence from it, but never to the extent where he can cancel it. Although he desires to create "... a novel that operates in terms of its own procedures and issues in its own conclusions, not one that operates in terms of the procedures of history and eventuates in conclusions that are checkable by history (as a child's schoolwork is checked by a schoolmistress), ... inevitably, in our culture, history will, with varying degrees of forcefulness, try to claim primacy, claim to be a master-form of discourse ..." (Attwell, 1990:101-102). As Attwell observes: "[Coetzee's] fiction itself engages history in the form of the narrative of colonialism ..."(Atwell, 1990:103).

\section{Thrift}

If insularity has an appropriate economy, it might be located in the word "thrift", which tells of the prime deployment of limited resources, such as one would find on an island or in an isolated situation. Coetzee has an especial fondness for the notion of "thrift", by means of which, as already implied, we can also link him to Beckett, or at least certain of Beckett's characters:

I do believe in spareness ... Spare prose and a spare, thrifty world: it's an unattractive part of my makeup that has exasperated people who have had to share their lives with me. On the other hand, I was reading George Bourne the other day, on rural England pre-1914. The key word for Bourne, a complex, value-laden word with a long history, is thrift: the culture of the western European peasantry was a culture of thrift. My family roots lie in that peasant culture, transplanted from Europe to Africa. So I am quite deeply ambivalent about disparaging thrift (Coetzee, 1992:20).

Thriftiness is endemic in Beckett, but is perhaps nowhere better apparent than in his permutations, based on the most mundane of elements, such as different types of biscuits, different sounds, different foot-wear. This is the thriftiness of an ascetic material impoverishment, Beckett's alternative to colluding with a rat-race for which he has no time. In other words, through this element of "thriff" we can ascribe socio-political resonances to both Coetzee and Beckett. Beckett's high-modernism perceives thrift as culminating in a product of net zero, but cannot efface its social dimension. Coetzee is very concerned with its social dimension. But in the end we must concede, with a cautionary Beckettian regard for a too simplistic dichotomising, that for Beckett thrift above all informs his relation with a desired nothingness, while for Coetzee it informs his relation, through writing, with the plenum of lived experience. In this way, in 
Coetzee the spare, bleak insularity of the apartheid state inspires a now consciously chosen isolationism both symptomatic and interrogative of its context, while in Beckett the more general alienation of the modernist world at large posits a remoteness that sees as pointless the need for such interrogation.

\section{References}

Adomo, Theodor \& Horkheimer, Max. 1986. Dialectic of Enlightenment. London : Verso.

Attwell, David. 1990. The problem of history in the fiction of J.M. Coetzee. In: Trump, Martin (ed.). Rendering things visible: Essays on South African literary culture. Johannesburg : Ravan. p. 94-133.

Beckett, Samuel. 1970. Watt. London : Calder \& Boyars.

Beckett, Samuel. 1973. Murphy. London : Picador.

Coetzee, J.M. 1986. Foe. Johannesburg : Ravan Press.

Coetzee, J.M. 1988. White writing: On the culture of letters in South Africa.

Sandton : Radix (in association with Yale University Press).

Coetzee, J.M. 1990. Age of iron. Harmondsworth : Penguin.

Coetzee, J.M. 1992. Doubling the point: Essays and interviews. David Attwell (ed.). Cambridge : Harvard University Press.

Kenner, Hugh. 1973. Samuel Beckett: A critical study. Berkeley and Los Angeles : University of California Press.

Smith, H. Lindsay. 1979. Anatomy of apartheid. Germiston : Khanya Publishers.

Waugh, Patricia (ed.). 1992. Postmodernism: A reader. London : Edward Amold. 